\title{
Concise Chemoenzymatic Synthesis of Fasamycin A
}

\author{
Jian Li, Hans Renata* \\ The Scripps Research Institute, Department of Chemistry, 130 Scripps Way, Jupiter, FL, 33458 USA
}

\begin{abstract}
We report the development of a chemoenzymatic approach towards fasamycin A, a halogenated naphthacenoid that exhibits activities against methicillin-resistant Staphylococcus aureus and vancomycin-resistant Enterococcus faecalis. The synthesis was accomplished in a convergent manner: two fragments were combined together via Michael-Dieckmann condensation to afford a dimethylnaphthacenone system. Finally, an enzymatic halogenation was employed to introduce the requisite chlorine substituent of the natural product at a late stage.
\end{abstract}

Antibiotic resistance is becoming one of the most pressing threats to human health, especially with the emergence of multi-drug resistant (MDR) pathogens that prove recalcitrant to existing treatments. ${ }^{1}$ Highlighting the urgency of the matter, the World Health Organization recently released a list of twelve 'priority pathogens' that exhibit resistance to a number of antibiotics, including carbapenem-resistant Acinetobacter baumanii and Pseudomonas aeruginosa, methicillin-resistant Staphylococcus aureus (MRSA) and vancomycin-resistant Enterococcus faecalis (VRE). Given their involvement in 'biological warfare' among bacteria, many bacterial secondary metabolites are known to be effective antimicrobials and these natural products make up the majority of antibiotics that are used in the clinic today. ${ }^{2}$ Despite this success, pathogenic bacteria constantly evolve new modes of resistance and new antibiotic candidates need to be constantly advanced to address this challenge.

In 2011, Brady and co-workers discovered two chlorinated polyaromatic natural products namely fasamycins A (1) and B (2) through heterologous expression of an environmental DNA gene cluster. ${ }^{3}$ Fasamycin A was noted to exhibit potent antibacterial activities against MRSA (MIC $=3.1 \mu \mathrm{g} / \mathrm{mL}$ ) and VRE $(\mathrm{MIC}=0.8 \mu \mathrm{g} / \mathrm{mL})$ by inhibiting FabF, a key enzyme in the biosynthesis of type II fatty acid in bacteria. ${ }^{4}$ FabF has been shown to be indispensable for bacterial cell viability and currently represents an underdeveloped target in antibacterial drug discovery. ${ }^{5}$ To date, only a few small molecules, mostly natural products, have been reported to act as inhibitors of this enzyme. By analyzing the organization of the gene cluster, Brady and co-workers also proposed a late stage enzymatic C$\mathrm{H}$ chlorination reaction catalyzed by a flavin-dependent halogenase (FDH) on naphthacemycin $\mathrm{Br}^{6}$ to furnish the fasamycins. Based on its unique biogenesis and its potential to be a lead compound for antibiotic development, we set out to develop a chemoenzymatic synthesis of fasamycin A.
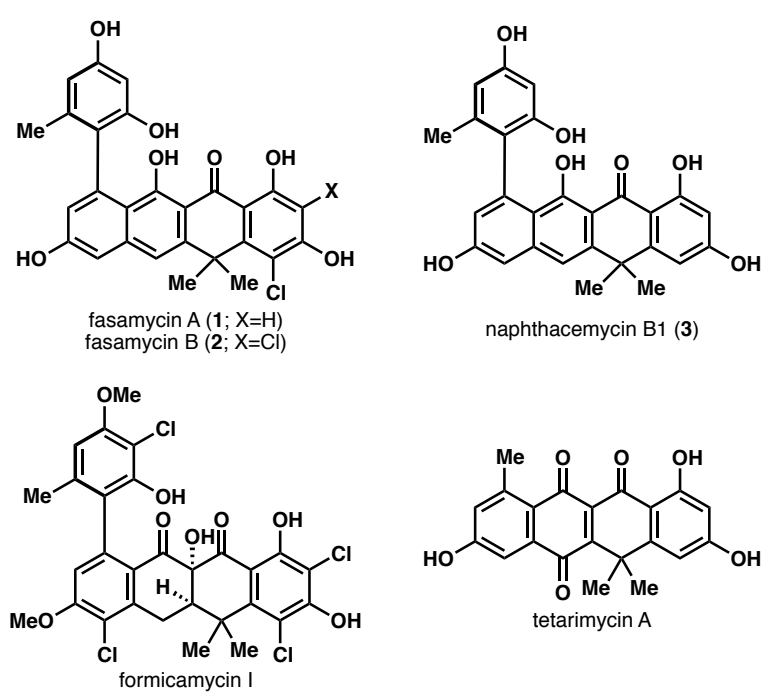

Figure 1. Structures of fasamycins A and B and related natural products.

The medicinal potential and the unique framework of this natural product family have stimulated two elegant chemical syntheses by the groups of Shia and Kraus. ${ }^{7,8}$ Additionally, Shia has also reported the first synthesis of a related natural product, BE-24566B, also known as ABX. ${ }^{9}$ Inspired by these chemical syntheses and the biosynthetic proposal, our retrosynthesis for 1 starts from disconnection of its $\mathrm{C}-\mathrm{Cl}$ bond via a late stage enzymatic chlorination to reveal naphthacemycin $\mathrm{B} 1$ (3). Here, we envisioned an opportunity to functionally characterize the FDH (hereby termed FasV) from fasamycin biosynthesis for the first time and perform initial investigations into its biocatalytic utility. Naphthacemycin B1 could be assembled convergently through a Michael-Dieckmann annulation featuring lactone $\mathbf{4}$ and enone $\mathbf{5}$, and the pendant arene could be installed by a Suzuki coupling. Lactone 4 could be traced back to Brassard's diene $\mathbf{6}$ and ynoate $\mathbf{7}$ via a Diels-Alder and lactonization sequence. Finally, enone $\mathbf{5}$ could be synthesized through a formal annulation involving resorcinol derivative $\mathbf{8}$ and an appropriate $6 \mathrm{C}$ coupling partner (e.g., 9).

\section{Scheme 1. Retrosynthetic Analysis of Fasamycin A}



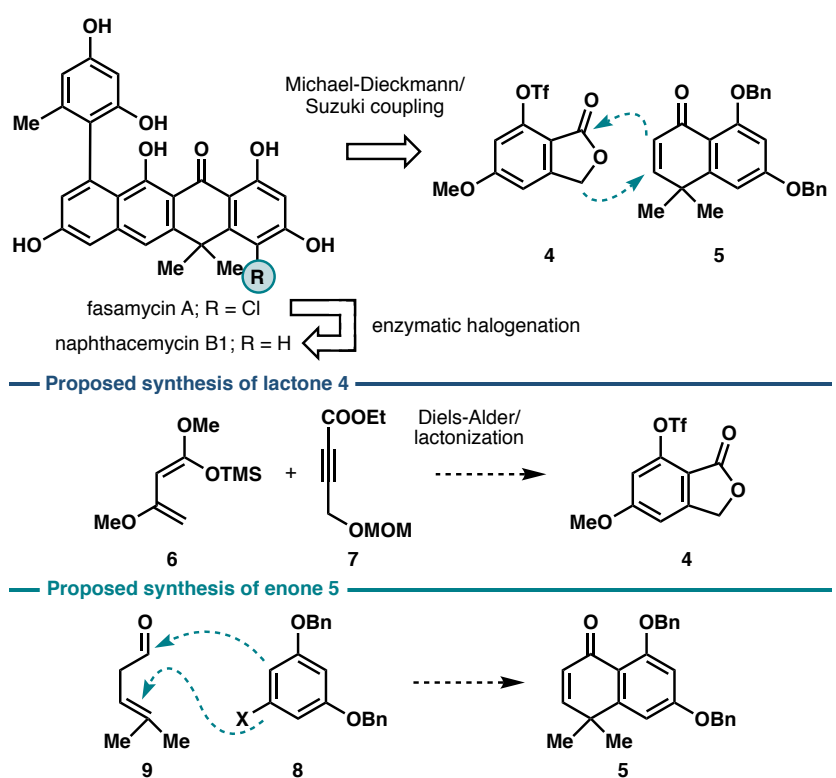

We first focused our efforts towards identifying an efficient route to enone $\mathbf{5}$. The same fragment has been synthesized previously by Shia through the use of hydrogen-atom-transfer(HAT)-based Giese coupling, followed by Friedel-Crafts acylation and oxidation state adjustment. Seeking to establish a complementary disconnection with reduced overall stepcount, we envisioned the use of Sigman's redox-relay Heck reaction $^{10}$ to forge the key quaternary carbon of 5. Gratifyingly, union of alkene $\mathbf{1 0}$ and boronic acid $\mathbf{1 1}$ under Sigman's conditions proceeded uneventfully (Scheme 2 ) to provide aldehyde 12 in $50 \%$ yield. $\mathrm{A} \mathrm{SnCl}_{4}$-induced intramolecular FriedelCrafts $^{11}$ cyclization gave benzylic alcohol 13 in $61 \%$ yield and this alcohol was directly oxidized to the corresponding enone in one pot by using IBX as an oxidant ${ }^{12}$ to complete the synthesis of enone 5 .

\section{Scheme 2. Synthesis of Enone 5}

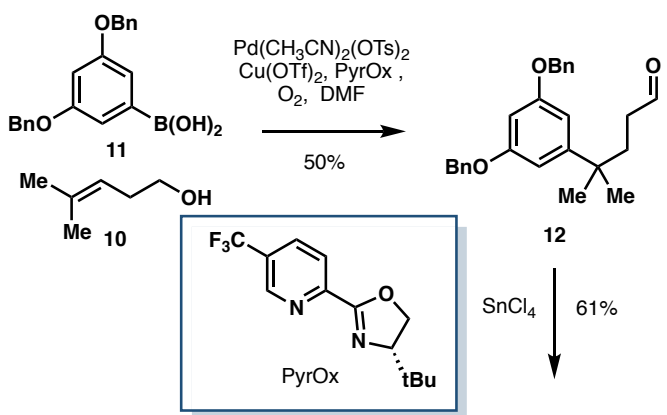<smiles>[CH]c1cc(OC)c2c(c1)C(C)(C)C=CC2=O</smiles>

5

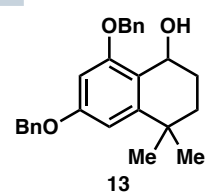

Towards lactone 4, we noted that a related structure had been prepared by Shia through the use of ring substitution/functionalization of a resorcinol derivative. We envisioned that a ring annulation strategy would allow for a more expedient access. Towards this goal, Brassard's diene $6^{13}$ and alkyne $7^{14}$ were utilized to construct lactone 14 through a sequential Diels-Alder reaction and acid-induced lactonization (Scheme 3). Triflation of the phenol group and conversion of the triflate group into arene side chain via standard Suzuki coupling conditions provided lactone 16 in $82 \%$ overall yield. LDA-induced
Michael-Dieckmann cyclization between $\mathbf{5}$ and $\mathbf{1 6}$, followed by treatment with $\mathrm{HCl}$ furnished the desired dimethylnaphthacenone ring system. Finally, global deprotection with $\mathrm{BBr}_{3}$ proceeded in $40 \%$ yield (over two steps) to complete our synthesis of naphthacemycin B1.

Scheme 3. Synthesis of Lactone 16 and Completion of the Synthesis of naphthacemycin B1

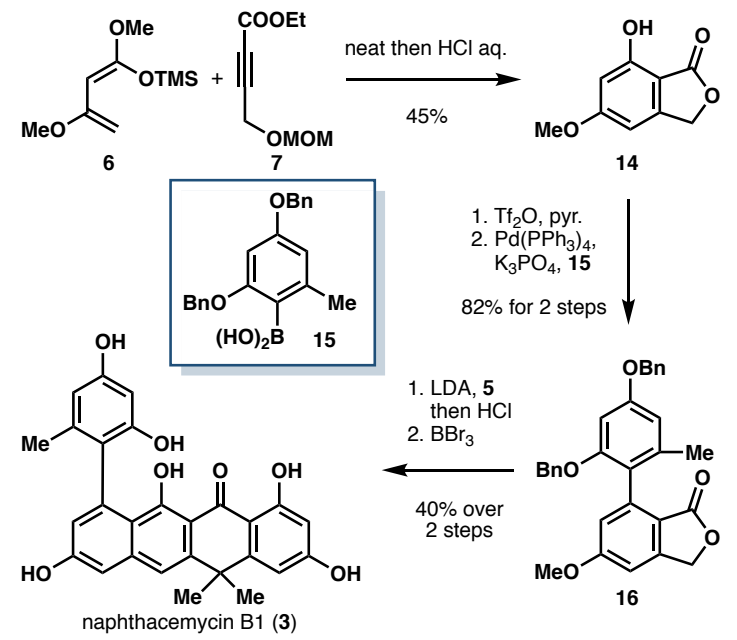

With naphthacemycin $B 1$ in hand, we set out to functionally characterize FasV and investigate its use in the final C-H chlorination step. FasV shares $59.8 \%$ and $55.4 \%$ sequence identity with ForV, a FDH from formicamycin biosynthesis, and AbxH, a FDH from BE-24566B biosynthesis. While no biosynthetic studies have been performed on the fasamycins, some of the late-stage tailoring steps in formicamycin and BE-24566B have begun to be elucidated. ${ }^{15,16}$ Notably, in frame deletion of forV resulted in the production of non-chlorinated precursors to the formicamycins and in trans complementation rescued the production of the formicamycins. Additionally, in vitro assays had been performed to verify the role of AbxH in BE-24566B biosynthesis.

Heterologous expressions of FasV and ForV as N-His6-tagged proteins resulted in satisfactory yields of soluble proteins, allowing us to start screening for an optimal set of C-H chlorination conditions. The two purified FDHs were tested in combination with five FAD reductases, namely Fre, ${ }^{17}$ SfFre (a Fre homolog from $S$. formicae, the native producer of the formicamycins), SsuE, ${ }^{18} \mathrm{CtcQ}^{19}$ and $\mathrm{HpaC}^{20}$ (Table 1). Despite extensive screening, only low conversions to the chlorinated products could be observed and several reductases (Fre and SfFre) failed to give any desired products at all. Additionally, a mixture of monochlorination regioisomers was consistently detected, though LC/MS analyses and comparison with authentic product standard showed that fasamycin A was always the major chlorinated product. Among the combinations tested, the FasV/CtcQ pair gave the highest conversion though the overall chlorination yield was still unsatisfactory. The enzymatic reaction was next performed on preparative scale and purification of the reaction mixture by preparative TLC afforded fasamycin A in pure form. To benchmark the enzymatic chlorination strategy, naphthacemycin B1 was submitted to electrophilic chlorination with several small-molecule reagents. However, intractable mixtures were consistently observed across all conditions tested. This observation suggests that despite its low efficiency, the enzymatic chlorination proceeds under much milder conditions than conventional 
chemical halogenations. Though the low conversion was disappointing, future enzyme engineering efforts or genome mining for enzyme homologs could potentially address this issue. Additionally, it is worth noting that during the characterization of the halogenase from BE-24566B biosynthesis, Lei, $\mathrm{Qu}$ and co-workers also observed only low conversion to the halogenated products despite the use of high enzyme loading. ${ }^{16}$

Table 1. Enzymatic Halogenation Screening ${ }^{a}$
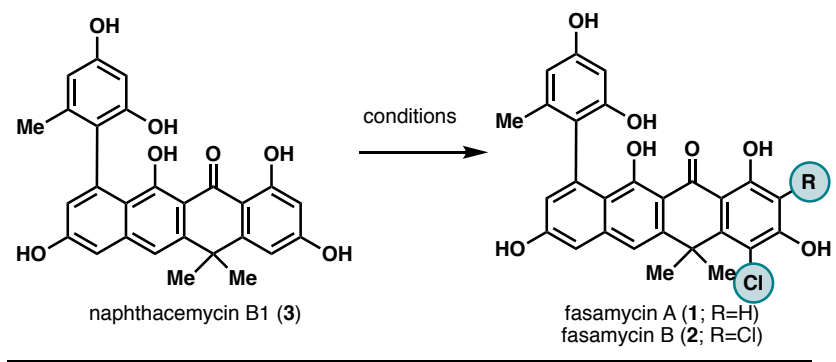

\begin{tabular}{lcc}
\hline Halogenase & Reductase & Conversion \\
\hline FasV & Fre & $0 \%$ \\
FasV & SfFre & $0 \%$ \\
FasV & SsuE & $3 \%$ as a mixture \\
\hline FasV & CtcQ & $7 \%$ as a mixture \\
\hline FasV & HpaC & $3-5 \%$ as a mixture \\
ForV & Fre & $0 \%$ \\
ForV & SfFre & $0 \%$ \\
ForV & SsuE & $3 \%$ as a mixture \\
ForV & CtcQ & $5 \%$ as a mixture \\
ForV & HpaC & $0 \%$ \\
\hline
\end{tabular}

${ }^{a}$ Standard conditions for screening: Naphthacemycin B1 (o.5 $\mathrm{mM}, 1$ equiv), NADH/NADPH (1 mM, 2 equiv), FAD (100 $\mu \mathrm{M}$, $20 \mathrm{~mol} \%)$, halogenase $(5 \mu \mathrm{M}, 1 \mathrm{~mol} \%)$, Reductase $(5 \mu \mathrm{M}, 1$ mol\%), buffer (20 mM phosphate $\mathrm{pH} 7.4,100 \mathrm{mM} \mathrm{NaCl}, 5 \mathrm{~mL}$ total volume), $12 \mathrm{~h}$.

In summary, we have accomplished the chemoenzymatic synthesis of fasamycin A. The western and eastern segments were concisely prepared and convergently assembled to furnish the naphthacemycin core skeleton. By relying on the native FDH from fasamycin biosynthesis, a late-stage enzymatic chlorination reaction was performed to install the chlorine substituent of the natural product. This work also provided the first direct biochemical confirmation of the halogenation activity of FasV and ForV, and presented our initial foray towards evaluating their performance and viability as late-stage halogenation biocatalysts. Finally, the route described herein lays down the blueprint for future chemoenzymatic preparation of other halogenated naphthacenone natural products and will facilitate the discovery of new antibiotics and their SAR studies.

\section{EXPERIMENTAL SECTION}

General materials and methods. Unless otherwise noted, all chemicals and reagents for chemical reactions were purchased at the highest commercial quality and used without further purification. Reactions were monitored by thin layer chromatography (TLC) and liquid chromatography/mass spectrometry (LC/MS). TLC was performed with $0.25 \mathrm{~mm}$ E. Merck silica plates (60F-254) using short-wave UV light as the visualizing agent, and ninhydrin, $\mathrm{KMnO} 4$, or phosphomolybdic acid and heat as developing agents. LC/MS was performed with Agilent 1260 Infinity System equipped with Poroshell 120 EC-C18 column (3.0 x $50 \mathrm{~mm}, 2.7$ micron). NMR spectra were recorded on a Bruker spetrometer and calibrated using residual undeuterated solvent. Optical rotations were measured on Autopol IV polarimeter (Rudolph Research Analytical).

Enzyme expression and purification. Expression vectors were used directly to transform electrocompetent $E$. coli strain BL21(DE3). Sonication was performed using a Qsonica Q500 sonicator. Purified enzymes were accessed via immobilized metal ion affinity chromatography with HisTrap HP column. Recombinant E. coli BL21(DE3) cells harboring plasmids that encode for the appropriate enzyme variants were cultured under standard conditions with IPTG induction. Cell were harvested by centrifugation $\left(4^{\circ} \mathrm{C}\right.$, $15 \mathrm{~min}, 3,000 \mathrm{xg}$ ), and the cell pellet was stored at $-20^{\circ} \mathrm{C}$ or below for at least $2 \mathrm{~h}$. Purification was performed with an AKTA pure FPLC system (GE Healthcare). The thawed cell pellet was resuspended in Ni-NTA buffer A $(25 \mathrm{mM}$ Tris $\bullet \mathrm{HCl}, 200 \mathrm{mM} \mathrm{NaCl}, 25$ $\mathrm{mM}$ imidazole, $\mathrm{pH} 9.0,4 \mathrm{~mL} / \mathrm{g}$ of cell wet weight) and lysed by sonication ( $3 \times 1 \mathrm{~min}, 50 \%$ duty cycle). The lysate was centrifuged at $15,000 \mathrm{xg}$ for $30 \mathrm{~min}$ at $4{ }^{\circ} \mathrm{C}$ to remove cell debris. The collected supernatant was subjected to a Ni-NTA chromatography step using a Ni Sepharose column (HisTrap-HP, GE healthcare, Piscataway, $\mathrm{NJ})$. The protein was eluted from the Ni Sepharose column using $25 \mathrm{mM}$ Tris $\bullet \mathrm{HCl}, 200 \mathrm{mM} \mathrm{NaCl}, 300 \mathrm{mM}$ imidazole, $\mathrm{pH}$ 8.0. Nipurified protein was buffer exchanged into $0.05 \mathrm{M}$ phosphate buffer ( $\mathrm{pH}=7.0$ ) using a $30 \mathrm{kDa}$ MW cut-off centrifugal filter. Protein concentrations were determined by A280 with calculated extinction coefficients as obtained at https://web.expasy.org/protparam. For storage, proteins were portioned into $100 \mu \mathrm{L}$ aliquots, flash frozen on liquid $\mathrm{N}_{2}$, and stored at $-80^{\circ} \mathrm{C}$.

4-(3,5-bis(benzyloxy)phenyl)-4-methylpentanal (12). A stirred solution of $\mathrm{Pd}\left(\mathrm{CH}_{3} \mathrm{CN}\right)_{2}(\mathrm{OTs})_{2}(159 \mathrm{mg}, 0.30 \mathrm{mmol}), \mathrm{Cu}(\mathrm{OTf})_{2}(54$ $\mathrm{mg}, 0.15 \mathrm{mmol})$, PyrOx (123 mg, $0.045 \mathrm{mmol})$ and $3 \AA$ molecular sieves $(750 \mathrm{mg})$ in DMF $(400 \mathrm{~mL})$ was stirred under $\mathrm{O}_{2}$ for $10 \mathrm{~min}$ at $22{ }^{\circ} \mathrm{C}$. To the resulting mixture were sequentially added alcohol 10 (500 mg, $4.99 \mathrm{mmol}$ ) and boronic acid 11 (1.67 g, $5.00 \mathrm{mmol})$ at $\mathrm{rt}$. The reaction mixture was stirred at room temperature for $24 \mathrm{~h}$ before it was quenched with saturated aq. $\mathrm{NaHCO}_{3}(400 \mathrm{~mL})$. The mixture so obtained was extracted with EtOAc $(3 \times 200 \mathrm{~mL})$. The combined organic phases were washed with brine $(400 \mathrm{~mL})$, dried over anhydrous $\mathrm{Na}_{2} \mathrm{SO}_{4}$, and filtered. After removal of the solvent under vacuum, the residue was subjected to flash column chromatography for purification using EtOAc/petroleum ether $(1: 10 \rightarrow 1: 4)$ as eluent to give aldehyde $\mathbf{1 2}(971 \mathrm{mg}, 50 \%)$ as a pale yellow oil: ${ }^{1} \mathrm{H}$ NMR (400 MHz, Acetone- $\left.d_{6}\right) \delta 9.59(\mathrm{~s}, 1 \mathrm{H}), 7.51-7.23(\mathrm{~m}, 10$ $\mathrm{H}), 6.64-6.58(\mathrm{~m}, 2 \mathrm{H}), 6.54(\mathrm{~s}, 1 \mathrm{H}), 5.10(\mathrm{~s}, 4 \mathrm{H}), 2.25-2.11(\mathrm{~m}$, $2 \mathrm{H}), 1.93-1.83(\mathrm{~m}, 2 \mathrm{H}) ;{ }^{13} \mathrm{C}$ NMR $\left(101 \mathrm{MHz}\right.$, Acetone- $\left.d_{6}\right) \delta 202.5$, $160.7,151.5,138.3,129.1,128.4,128.3,106.3,99.9,70.3,40.4$, $37.9,36.2,32.1$; HRMS (ESI) $m / z[\mathrm{M}+\mathrm{Na}]^{+}$calcd for $\mathrm{C}_{26} \mathrm{H}_{28} \mathrm{O}_{3} \mathrm{Na}$ 411.1931 , found 411.1933 .

6,8-bis(benzyloxy)-4,4-dimethyl-1,2,3,4-tetrahydronaphthalen-1ol (13). To a stirred solution of aldehyde $12(971 \mathrm{mg}, 2.50 \mathrm{mmol})$ in $\mathrm{CH}_{2} \mathrm{Cl}_{2}(10 \mathrm{~mL})$ was added $\mathrm{SnCl}_{4}\left(3 \mathrm{~mL}, 1.0 \mathrm{M}\right.$ in $\left.\mathrm{CH}_{2} \mathrm{Cl}_{2}\right)$ at $-78{ }^{\circ} \mathrm{C}$. The reaction mixture was stirred at the same temperature for $4 \mathrm{~h}$ and then quenched with saturated aq. $\mathrm{NaHCO}_{3}(20 \mathrm{~mL})$. The resulting mixture was extracted with EtOAc $(3 \times 20 \mathrm{~mL})$, and the combined organic phases were washed with brine $(150 \mathrm{~mL})$ and dried over anhydrous $\mathrm{Na}_{2} \mathrm{SO}_{4}$. After filtration and evaporation of the solvent under vacuum, the residue was subjected to flash column chromatography for purification using EtOAc/petroleum ether $(1: 3 \rightarrow 1: 1)$ as eluent to give alcohol $13(592 \mathrm{mg}, 61 \%)$ as a pale yellow oil: ${ }^{1} \mathrm{H}$ NMR $\left(400 \mathrm{MHz}\right.$, Acetone- $\left.d_{6}\right) \delta 7.54-7.29(\mathrm{~m}, 10 \mathrm{H})$, $6.65(\mathrm{~d}, J=2.3 \mathrm{~Hz}, 1 \mathrm{H}), 6.58(\mathrm{~d}, J=2.4 \mathrm{~Hz}, 1 \mathrm{H}), 5.20-5.07(\mathrm{~m}$, $4 \mathrm{H}), 5.05-4.94(\mathrm{~m}, 1 \mathrm{H}), 1.93-1.76(\mathrm{~m}, 2 \mathrm{H}), 1.53-1.38(\mathrm{~m}, 1 \mathrm{H})$, $1.29(\mathrm{~s}, 3 \mathrm{H}), 1.17(\mathrm{~s}, 3 \mathrm{H}) ;{ }^{13} \mathrm{C}$ NMR $\left(101 \mathrm{MHz}\right.$, Acetone- $\left.d_{6}\right) \delta$ 159.7, 158.7, 148.7, 138.4, 138.3, 129.1, 129.1, 128.4, 128.4, 128.3, $128.1,120.7,104.7,98.5,70.5,70.2,62.1,34.7,33.7,31.5,30.8$, 
27.9; HRMS (ESI) $m / z[\mathrm{M}+\mathrm{Na}]^{+}$calcd for $\mathrm{C}_{26} \mathrm{H}_{28} \mathrm{O}_{3} \mathrm{Na} 411.1931$, found 411.1937 .

6,8-bis(benzyloxy)-4,4-dimethylnaphthalen-1(4H)-one (5). To a stirred solution of alcohol $13(300 \mathrm{mg}, 0.772 \mathrm{mmol})$ in DMSO (3 $\mathrm{mL})$ was added IBX (476 $\mathrm{mg}, 1.70 \mathrm{mmol})$ at $22{ }^{\circ} \mathrm{C}$. The resulting mixture was heated to $100^{\circ} \mathrm{C}$ and stirred at that temperature for 48 $\mathrm{h}$ before it was cooled to $22^{\circ} \mathrm{C}$ and diluted with EtOAc $(20 \mathrm{~mL})$. The resultant mixture was sequentially washed with saturated aq. $\mathrm{Na}_{2} \mathrm{~S}_{2} \mathrm{O}_{3}(10 \mathrm{~mL})$ and brine $(10 \mathrm{~mL})$. The combined organic phases were dried over anhydrous $\mathrm{Na}_{2} \mathrm{SO}_{4}$ and filtered. The solvent was evaporated under vacuum, and the residue was rapidly purified by flash column chromatography with EtOAc/petroleum ether (1:10 $\rightarrow 1: 2)$ to give enone $\mathbf{5}(249 \mathrm{mg}, 84 \%)$ as a colorless oil: $1 \mathrm{H}$ NMR $\left(400 \mathrm{MHz}, \mathrm{CDCl}_{3}\right) \delta$ 7.74-7.59 (m, $\left.2 \mathrm{H}\right), 7.48-7.27(\mathrm{~m}, 8 \mathrm{H}), 6.70$ $6.63(\mathrm{~m}, 2 \mathrm{H}), 6.56(\mathrm{~d}, J=2.3 \mathrm{~Hz}, 1 \mathrm{H}), 6.24(\mathrm{~d}, J=10.1 \mathrm{~Hz}, 1 \mathrm{H})$, 5.19 (s, $2 \mathrm{H}), 5.10(\mathrm{~s}, 2 \mathrm{H}), 1.42(\mathrm{~s}, 6 \mathrm{H}) ;{ }^{13} \mathrm{C} \mathrm{NMR}(101 \mathrm{MHz}$, $\left.\mathrm{CDCl}_{3}\right) \delta 184.0,162.5,161.4,154.9,153.0,136.9,136.2,128.9$, $128.7,128.5,128.4,127.8,127.7,126.8,115.2,105.0,99.5,70.8$, 70.3, 38.1, 30.7; HRMS (ESI) $m / z[\mathrm{M}+\mathrm{Na}]^{+}$calcd for $\mathrm{C}_{26} \mathrm{H}_{24} \mathrm{O}_{3} \mathrm{Na}$ 407.1618, found 407.1625 .

7-hydroxy-5-methoxyisobenzofuran-1(3H)-one (14). To a stirred solution of alkyne $7(1.72 \mathrm{~g}, 10.0 \mathrm{mmol})$ in toluene $(10 \mathrm{~mL})$ was added Brassard's diene $6(2.43 \mathrm{~g}, 12.0 \mathrm{mmol})$ at $22^{\circ} \mathrm{C}$. The resulting mixture was heated to $110^{\circ} \mathrm{C}$ and stirred at the same temperature for $12 \mathrm{~h}$ before it was cooled to $22^{\circ} \mathrm{C}$. $\mathrm{HCl}$ was added $(10 \mathrm{~mL}$, $1.0 \mathrm{M}$ in ethyl acetate) and the resulting mixture was stirred for 3 h. The organic phase was diluted with $100 \mathrm{~mL}$ ethyl acetate, washed with brine $(100 \mathrm{~mL})$, dried over anhydrous $\mathrm{Na}_{2} \mathrm{SO}_{4}$ and filtered. The solvent was evaporated under vacuum, and the residue was purified by flash column chromatography with EtOAc/petroleum ether $(1: 10 \rightarrow 1: 1)$ to give lactone $14(810 \mathrm{mg}, 45 \%)$ as a white powder: $1 \mathrm{H} \mathrm{NMR}\left(400 \mathrm{MHz}\right.$, Acetone- $\left.d_{6}\right) \delta 8.59(\mathrm{~s}, 1 \mathrm{H})$, 6.69-6.62 (m, 1 H), 6.48-6.42 (m, 1 H), 5.26 (S, 2 H), 3.88 (s, 3 $\mathrm{H}) ;{ }^{13} \mathrm{C}$ NMR (101 MHz, Acetone- $\left.d_{6}\right) \delta 171.2,168.0,158.6,151.4$, 105.5, 102.1, 100.5, 70.5, 56.5; HRMS (ESI) $m / z$ [M + Na]+ calcd for $\mathrm{C}_{9} \mathrm{H}_{8} \mathrm{O}_{4} \mathrm{Na}$ 203.0315, found 203.0315.

7-(2,4-bis(benzyloxy)-6-methylphenyl)-5-methoxyisobenzofuran1(3H)-one (16). To a stirred solution of lactone $14(901 \mathrm{mg}, 5.0$ mmol) in $\mathrm{CH}_{2} \mathrm{Cl}_{2}(15 \mathrm{~mL})$ were sequentially added pyridine (804 $\mu \mathrm{L}, 10 \mathrm{mmol})$ and $\mathrm{Tf}_{2} \mathrm{O}(1.01 \mathrm{~mL}, 6.0 \mathrm{mmol})$ at $-20^{\circ} \mathrm{C}$. The reaction mixture was stirred at the same temperature for $2 \mathrm{~h}$ before it was quenched with saturated aq. $\mathrm{NaHCO}_{3}(20 \mathrm{~mL})$. The resulting mixture was extracted with EtOAc $(3 \times 20 \mathrm{~mL})$, and the combined organic phases were washed with brine $(150 \mathrm{~mL})$ and dried over anhydrous $\mathrm{Na}_{2} \mathrm{SO}_{4}$. After filtration and evaporation of the solvent under vacuum, the triflated lactone was obtained as a pale yellow solid $(1.56 \mathrm{~g}, 99 \%)$, which was taken to the next step without further purification. To a stirred solution of the triflate and boronic acid $15(2.44 \mathrm{~g}, 7.0 \mathrm{mmol})$ in toluene $(20 \mathrm{~mL})$ were sequentially added $\mathrm{Pd}\left(\mathrm{PPh}_{3}\right)_{4}(289 \mathrm{mg}, 0.25 \mathrm{mmol})$ and $\mathrm{K}_{3} \mathrm{PO}_{4}(10 \mathrm{~mL}, 1.0 \mathrm{M}$ in water). The resultant mixture was heated to $110^{\circ} \mathrm{C}$ and stirred at the same temperature for $8 \mathrm{~h}$ before it was cooled to $22^{\circ} \mathrm{C}$. The reaction mixture was diluted with $50 \mathrm{~mL}$ ethyl acetate, washed with brine $(100 \mathrm{~mL})$, dried over anhydrous $\mathrm{Na}_{2} \mathrm{SO}_{4}$ and filtered. The solvent was evaporated under vacuum, and the residue was purified by flash column chromatography with EtOAc/petroleum ether $(1: 50 \rightarrow 1: 10)$ to give lactone $\mathbf{1 6}(1.91 \mathrm{~g}, 82 \%)$ as a colorless oil: $1 \mathrm{H} \mathrm{NMR}\left(400 \mathrm{MHz}, \mathrm{CDCl}_{3}\right) \delta 7.52-7.07(\mathrm{~m}, 10 \mathrm{H}), 6.86(\mathrm{~s}, 2 \mathrm{H})$, $6.61-6.56(\mathrm{~m}, 1 \mathrm{H}), 6.54(\mathrm{~d}, J=2.3 \mathrm{~Hz}, 1 \mathrm{H}), 5.18(\mathrm{dd}, J=7.9,0.8$ $\mathrm{Hz}, 2 \mathrm{H}), 5.05$ (s, $2 \mathrm{H}), 4.96(d, \mathrm{~J}=1.9 \mathrm{~Hz}, 2 \mathrm{H}), 3.88$ (s, $3 \mathrm{H}), 2.09$ $(\mathrm{s}, 3 \mathrm{H}) ;{ }^{13} \mathrm{C}$ NMR $\left(101 \mathrm{MHz}, \mathrm{CDCl}_{3}\right) \delta 169.7,164.1,159.6,157.1$, 149.8, 139.7, 138.0, 137.3, 137.1, 128.7, 128.4, 128.1, 127.8, 127.5, 126.9, 119.1, 118.9, 117.0, 108.0, 105.1, 98.6, 70.5, 70.1, 68.2, 55.9, 20.6; HRMS (ESI) $m / z[\mathrm{M}+\mathrm{Na}]+$ calcd for $\mathrm{C}_{30} \mathrm{H}_{26} \mathrm{O}_{5} \mathrm{Na} 489.1672$, found 489.1679 .
Naphthacemycin B1 (3). To a stirred solution of lactone 16 (446 $\mathrm{mg}, 1.00 \mathrm{mmol})$ and enone $5(384 \mathrm{mg}, 1.00 \mathrm{mmol})$ in THF $(4 \mathrm{~mL})$ was added LDA $(0.6 \mathrm{~mL}, 2.0 \mathrm{M}$ in THF/heptane/ethylbenzene, 1.2 $\mathrm{mmol}$ ) at $-78^{\circ} \mathrm{C}$. The reaction mixture was warmed to $22{ }^{\circ} \mathrm{C}$ and stirred at that temperature for $48 \mathrm{~h}$ before it was quenched with $\mathrm{HCl}$ (3.0 $\mathrm{mL}, 1.0 \mathrm{M}$ in ethyl acetate). The resulting mixture was extracted with EtOAc $(3 \times 50 \mathrm{~mL})$. The combined organic phases were washed with brine $(150 \mathrm{~mL})$ and dried over anhydrous $\mathrm{Na}_{2} \mathrm{SO}_{4}$. After filtration and removal of the solvent under vacuum, the residue was purified by flash column chromatography with EtOAc/petroleum ether $(1: 60 \rightarrow 1: 10)$ to give $374 \mathrm{mg}$ of pre-naphthacemycin $\mathrm{B} 1$ as yellow oil. To a stirred solution of this compound in $\mathrm{CH}_{2} \mathrm{Cl}_{2}(3 \mathrm{~mL})$ was added $\mathrm{BBr}_{3}\left(2.0 \mathrm{~mL}, 1.0 \mathrm{M}\right.$ in $\left.\mathrm{CH}_{2} \mathrm{Cl}_{2}\right)$ at $-78^{\circ} \mathrm{C}$. The resulting mixture was warmed to $22{ }^{\circ} \mathrm{C}$ and stirred at the same temperature for $8 \mathrm{~h}$ before it was quenched with saturated aq. $\mathrm{NaHCO}_{3}(20 \mathrm{~mL})$. The resultant mixture was extracted with EtOAc $(3 \times 20 \mathrm{~mL})$, and the combined organic phases were washed with brine $(50 \mathrm{~mL})$ and dried over anhydrous $\mathrm{Na}_{2} \mathrm{SO}_{4}$. After filtration and evaporation of the solvent under vacuum, the residue was subjected to flash column chromatography for purification using EtOAc/petroleum ether $(1: 3 \rightarrow 1: 1)$ as eluent to give naphthacemycin B1 3 (183 mg, 40\%) as a yellow solid: ${ }^{1} \mathrm{H}$ NMR $(600 \mathrm{MHz}$, methanol- $\left.d_{4}\right) \delta 7.36(\mathrm{~s}, 1 \mathrm{H}), 7.05(\mathrm{~d}, J=2.5 \mathrm{~Hz}, 1 \mathrm{H}), 6.72(\mathrm{~d}, J=$ $2.5 \mathrm{~Hz}, 1 \mathrm{H}), 6.65$ (d, $J=2.3 \mathrm{~Hz}, 1 \mathrm{H}), 6.27(\mathrm{dd}, J=2.4,0.8 \mathrm{~Hz}, 1$ H), 6.24 (dd, $J=2.3,0.6 \mathrm{~Hz}, 1 \mathrm{H}), 6.21(\mathrm{~d}, J=2.2 \mathrm{~Hz}, 1 \mathrm{H}), 1.88$ $(\mathrm{d}, J=0.7 \mathrm{~Hz}, 3 \mathrm{H}), 1.71(\mathrm{~s}, 3 \mathrm{H}), 1.69(\mathrm{~s}, 3 \mathrm{H}) ;{ }^{13} \mathrm{C} \mathrm{NMR}(151$ $\mathrm{MHz}$, Methanol- $\left.d_{4}\right) \delta 210.5,191.6,166.9,166.6,166.3,160.1$, $157.5,155.8,155.4,146.5,142.9,140.8,138.3,124.5,122.5,118.2$, 116.1, 110.1, 108.8, 108.7, 107.6, 106.9, 102.0, 100.8, 39.7, 34.7, $34.5,20.7$; HRMS (ESI) $m / z[\mathrm{M}+\mathrm{Na}]+$ calcd for $\mathrm{C}_{27} \mathrm{H}_{22} \mathrm{O}_{7} \mathrm{Na}$ 481.1258 , found 481.1264 .

General Condition for Enzymatic Halogenation Screening. To a 5 $\mathrm{mL}$ phosphate-buffered saline solution $(20 \mathrm{mM}$ phosphate $\mathrm{pH} 7.4$, $100 \mathrm{mM} \mathrm{NaCl}$ ) in $20 \mathrm{~mL}$ scintillation vial was added NADH or NADPH (1 mM final concentration), FAD (100 $\mu \mathrm{M}$ final concentration), $0.25 \mathrm{~mL}$ of naphthacemycin $\mathrm{B} 1$ stock solution $(10 \mathrm{mM}$ in methanol, ca. $0.5 \mathrm{mM}$ final concentration), halogenase $(5.0 \mu \mathrm{M}$ final concentration) and reductase $(5.0 \mu \mathrm{M}$ final concentration). The vial was sealed and shaken for $12 \mathrm{~h}$ at $22^{\circ} \mathrm{C}, 200 \mathrm{rpm}$. The mixture was extracted with ethyl acetate $(5 \mathrm{~mL})$. The organic layer was concentrated under vacuum and analyzed by reverse phase liquid chromatography.

Fasamycin $A$ (1). To a $5 \mathrm{~mL}$ phosphate-buffered saline solution (20 $\mathrm{mM}$ phosphate $\mathrm{pH} 7.4,100 \mathrm{mM} \mathrm{NaCl})$ in $20 \mathrm{~mL}$ scintillation vial was added NADH (1 mM final concentration), FAD (100 $\mu \mathrm{M}$ final concentration), $0.25 \mathrm{~mL}$ of naphthacemycin B1 stock solution (10 $\mathrm{mM}$ in methanol, ca. $0.5 \mathrm{mM}$ final concentration), FasV $(5.0 \mu \mathrm{M}$ final concentration) and CtcQ $(5.0 \mu \mathrm{M}$ final concentration). The vial was sealed and shaken for $12 \mathrm{~h}$ at $22{ }^{\circ} \mathrm{C}, 200 \mathrm{rpm}$. The mixture was extracted with ethyl acetate $(5 \mathrm{~mL})$. To provide sufficient material for isolation, twenty reactions were performed in parallel and combined at the end. The combined organic layers were concentrated under vacuum and purified with preparative thin layer chromatography (EtOAc/petroleum ether 1:2) to give fasamycin A (1.3 mg, $5.2 \%)$ as a yellow solid: $1 \mathrm{H} \mathrm{NMR}\left(400 \mathrm{MHz}\right.$, Methanol- $\left.d_{4}\right) \delta$ 7.34 (s, $1 \mathrm{H}), 7.05$ (d, $J=2.5 \mathrm{~Hz}, 1 \mathrm{H}), 6.72(\mathrm{~d}, J=2.5 \mathrm{~Hz}, 1 \mathrm{H})$, $6.45(\mathrm{~d}, J=1.0 \mathrm{~Hz}, 1 \mathrm{H}), 6.26(\mathrm{dd}, J=2.4,0.8 \mathrm{~Hz}, 1 \mathrm{H}), 6.23(\mathrm{~d}, J$ $=2.3 \mathrm{~Hz}, 1 \mathrm{H}), 2.06(\mathrm{~s}, 3 \mathrm{H}), 2.04(\mathrm{~s}, 3 \mathrm{H}), 1.88(\mathrm{~s}, 3 \mathrm{H}) ;{ }^{13} \mathrm{C} \mathrm{NMR}$ $\left(151 \mathrm{MHz}\right.$, Methanol- $\left.d_{4}\right) \delta 191.6,166.6,165.5,160.3,157.5,155.5$, $150.0,149.2$, 143.5, 140.9, 138.2, 124.4, 122.6, 117.8, 117.0, 109.9, 108.8, 106.3, 103.6, 100.8, 40.7, 30.3, 30.2, 20.7; HRMS (ESI) $m / z$ $[\mathrm{M}+\mathrm{Na}]+$ calcd for $\mathrm{C}_{27} \mathrm{H}_{21} \mathrm{ClO}_{7} \mathrm{Na} 515.0868$, found 515.0877. [ $\alpha$ ] ${ }_{\mathrm{D}}^{24}=+5.7(\mathrm{c}=0.20$ in $\mathrm{MeOH})$.

\section{ASSOCIATED CONTENT}




\section{Supporting Information}

Protein and DNA sequences, ${ }^{1} \mathrm{H}$ and ${ }^{13} \mathrm{C}$ NMR data and HPLC traces.

\section{AUTHOR INFORMATION}

\section{Corresponding Author}

hrenata@scripps.edu

\section{ACKNOWLEDGMENT}

Funding for this work is generously provided by the National Institutes of Health (grant GM128895). We thank Prof. David $\mathrm{H}$. Sherman and Dr. Amy E. Fraley for providing plasmid pET11a-HpaC (encoding for $\mathrm{HpaC}$ flavin reductase). We acknowledge the Roush, Bannister, and Shen laboratories for generous access to their reagents and instrumentation.

\section{REFERENCES}

(1) Pearson, H. 'Superbug' hurdles key drug barrier. Nature 2002, 418, 469.(single page)

(2) Clardy, J.; Fischbach, M. A.; Walsh, C. T. New Antibiotics from Bacterial Natural Products. Nat. Biotechnol. 2006, 24, 1541-1550.

(3) Feng, Z.; Kallifidas, D.; Brady S. F. Functional Analysis of Environmental DNA-derived Type II Polyketide Synthases Reveals Structurally Diverse Secondary Metabolites. Proc. Natl. Acad. Sci. U.S.A. 2011, 108, 12629-12634.

(4) Feng, Z.; Chakraborty, D.; Dewell, S. B.; Reddy, B. V.; Brady, S. F. Environmental DNA-Encoded Antibiotics Fasamycins A and B Inhibit FabF in Type II Fatty Acid Biosynthesis. J. Am. Chem. Soc. 2012, 134, 2981-2987.

(5) Heath, R.; White, S.; Rock, C. Inhibitors of Fatty Acid Synthesis as Antimicrobial Chemotherapeutics. Appl. Microbiol. Biotechnol. 2002, 58, 695-703.

(6) Fukumoto, A.; Kim, Y.-P.; Matsumoto, A.; Takahashi, Y.; Suzuki, M.; Onodera, H.; Tomoda, H.; Matsui, H.; Hanaki, H.; Iwatsuki, M.; Ōmura S.; Shiomi K. Naphthacemycins, Novel Circumventors of $\beta$ lactam Resistance in MRSA, Produced by Streptomyces sp. KB-3346-5. I. The Taxonomy of the Producing Strain, and the Fermentation, Isolation and Antibacterial Activities. J. Antibiot. 2017, 70, 562-567.

(7) Huang, J.-K.; Yang Lauderdale, T.-L.; Lin, C.-C.; Shia, K.-S. Total Synthesis of Tetarimycin A, $( \pm)$-Naphthacemycin A9, and $( \pm)$ Fasamycin A: Structure-Activity Relationship Studies against DrugResistant Bacteria. J. Org. Chem. 2018, 83, 6508-6523.

(8) Wang, S.; Kraus G. A.; Synthesis of $( \pm)$-Naphthacemycin $A_{9}$. J. Org. Chem. 2018, 83, 15549-15552.
(9) Huang, J.-K.; Yang Lauderdale, T.-L.; Shia, K.-S. Studies on Antibiotics Active against Resistant Bacteria. Total Synthesis of MRSAActive Tetarimycin A and Its Analogues. Org. Lett. 2015, 17, 4248-4251.

(10) (a) Mei, T.-S.; Werner, E.W.; Burckle, A.J.; Sigman, M.S. Enantioselective Redox-Relay Oxidative Heck Arylations of Acyclic Alkenyl Alcohols using Boronic Acids. J. Am. Chem. Soc. 2013, 135, 6830-6833. (b) Mei, T.-S.; Patel, H. H.; Sigman, M. S. Enantioselective Construction of Remote Quaternary Stereocentres. Nature 2014, 508, 340-344.

(11) Genot, A.; Florent, J. C.; Monneret, C. Anthracyclinone. 3. Chiral pool synthesis of anthracyclinones via tetralin intermediates. J. Org. Chem. 1987, 52, 1057-1063.

(12) Nicolaou, K. C.; Montagnon, T.; Baran, P. S.; Zhong Y.-L. Iodine(V) Reagents in Organic Synthesis. Part 4. o-Iodoxybenzoic Acid as a Chemospecific Tool for Single Electron Transfer-Based Oxidation Processes. J. Am. Chem. Soc. 2002, 124, 2245-2258.

(13) Savard, J.; Brassard, P. Regiospecific Syntheses of Quinones Using Vinylketene Acetals Derived from Unsaturated Esters. Tetrahedron Lett. 1979, 20, 4911-4914.

(14) Piers, E.; Tillyer, R. D. Dilithium (trimethylstannyl)(2thienyl)(cyano)cuprate, a synthetically useful higher-order cuprate reagent. J. Org. Chem. 1987, 53, 5366-5369.

(15) Qin, Z.; Munnoch, J. T.; Devine, R.; Holmes, N. A.; Seipke, R. F.; Wilkinson, K. A.; Wilkinson B.; Hutchings, M. I. Formicamycins, Antibacterial Polyketides Produced by Streptomyces formicae Isolated from African Tetraponera Plant-ants. Chem. Sci., 2017, 8, 3218-3227.

(16) Mei, X.; Yan, X.; Zhang, H.; Yu, M.; Shen, G.; Zhou, L.; Deng, Z.; Lei, C.; Qu, X. Expanding the Bioactive Chemical Space of Anthrabenzoxocinones through Engineering the Highly Promiscuous Biosynthetic Modification Steps. ACS Chem. Biol. 2018, 13, 200-206.

(17) Spyrou, G.; Haggård-Ljungquist, E.; Krook, M.; Jörnvall, H.; Nilsson, E.; Reichard, P. Characterization of the Flavin Reductase Gene (fre) of Escherichia coli and Construction of a Plasmid for Overproduction of the Enzyme. J. Bacteriol. 1991, 173, 3673-3679.

(18) van Der Ploeg, J. R.; Iwanicka-Nowicka R.; Bykowski, T.; Hryniewicz, M. M.; Leisinger, T. The Escherichia coli ssuEADCB Gene Cluster is Required for the Utilization of Sulfur from Aliphatic Sulfonates and is Regulated by the Transcriptional Activator Cbl. J. Biol. Chem. 1999, 274, 29358-29365.

(19) Zhu, T.; Cheng, X.; Liu, Y.; Deng, Z.; You, D. Deciphering and Engineering of the Final Step Halogenase for Improved Chlortetracycline Biosynthesis in Industrial Streptomyces aureofaciens. Metab. Eng. 2013, 19, 69-78.

(20) Prieto, M. A.; Garcia, J. L. Molecular Characterization of 4-hydroxyphenylacetate 3-hydroxylase of Escherichia coli. A Two-protein Component Enzyme. J. Biol. Chem. 1994, 269, 22823-22829. 


\section{TOC}

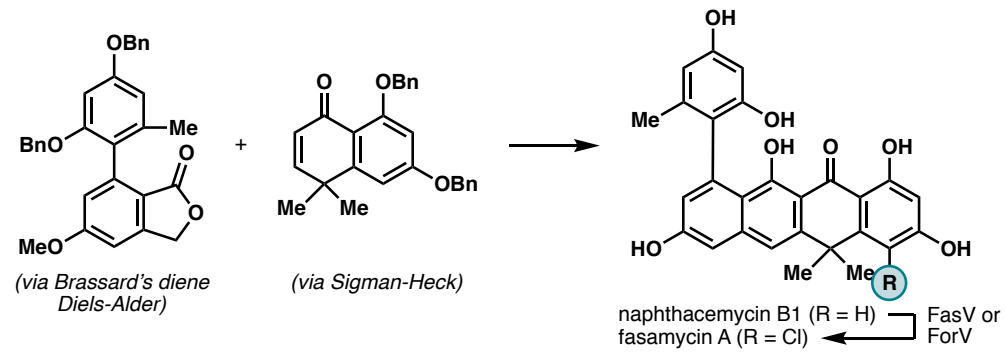

